\title{
Snow accumulation distribution on Spitsbergen, Svalbard, in 1997
}

\author{
J-G. WINTHER, O. BRULAND, K. SAND, A. KILLINGTVEIT and D. MARECHAL
}

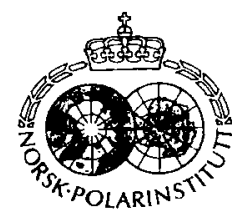

Winther, J-G., Bruland, O., Sand, K., Killingtveit, Å. \& Marechal, D. 1998: Snow accumulation distribution on Spitsbergen, Svalbard, in 1997. Polar Research 17(2), 155-164.

A survey of the regional snow accumulation variability on Spitsbergen, Svalbard, was carried out during three field campaigns in May 1997. The survey was carried out along three transects from west-to-east approximately at the following latitudes: $77^{\circ} 30^{\prime}, 78^{\prime \prime}$ and $78^{\circ} 50^{\prime}$ degrees north. The altitudes span from sea level to 1000 metres elevation. Snow depth was measured with two different ground-penetrating radar systems, PulsEKKO (450 MHz) and GSSI SIR System-2 $(500 \mathrm{MHz})$, pulled behind snew machines. Snow characteristics such as snow temperature, snow density and stratigraphy were measured in snow pits in nine areas, three along each transect. Our data suggest the following: (1) the accumulation-elevation gradients vary from $3 \mathrm{~mm} / 100 \mathrm{~m}$ in the northeast to $237 \mathrm{~mm} / 100 \mathrm{~m}$ in the central-south with an average value of $104 \mathrm{~mm} / 100 \mathrm{~m}$ for all measurements: (2) snow accumulation was 38 to $49 \%$ higher at the eastern coast than at the western coast; (3) a clear minimum in accumulation (or continental climate) is seen for the central (inland) locations in the middle and northern transects while no such minimum exists along the southern transect; (4) a south-to-north gradient produces 55\% and $40 \%$ less snow accumulation at the northern locations compared to the southem locations at the western and eastern coasts, respectively. These drops in winter snow accumulation occur over a distance of less than $200 \mathrm{~km}$.

Jan-Gunnar Winther, Norwegian Polar Institute, N-9005 Tromsф, Norway; Oddbjørn Bruland, SINTEF Civil and Environmental Engineering, N-7034 Trondheim, Norway; Knut Sand, The University Courses on Svalbard, P.O. Box 156, N-9170 Longyearbyen. Norway; Anund Killingtveit and David Marechal, Department of Hydraulic and Environmental Engineering, Norwegian University of Science and Technology, N-7034 Trondheim, Norway.

\section{Introduction}

A study of the water balance on Svalbard has been carried out since 1991 (Killingtveit et al. 1996). Measurements have been recorded on summer precipitation, snow accumulation, snow distribution. and evaporation. Other data such as mass balance of glaciers, content of liquid water within the active layer of soil, and the ground water balance have also been retrieved.

In recent years, a number of studies have been undertaken on Svalbard which are related to snow distribution within smaller basins, at particular glaciers, as well as point measurements. Some studies have a main focus on glacier mass balance (Hagen 1996; Hagen \& Liest $\varnothing 1$ 1987, 1990; Jania 1994; Leufauconnier et al. 1994). Krenke and others (1986) have calculated snow accumulation at the equilibrium line altitude (ELA) for the southern areas of Spitsbergen. Tveit \& Killingtveit (1996) collected data on snow distribution in the catchments of Bayelva, De Geer-elva and Endalselva/Isdammen, while another group measured snow accumulation in Liefdefjorden (northwestern Spitsbergen) for the period 19901992 (Scherer pers. commun.). Common for all these studies is the spatial restriction to local areas of special interest.

In contrast to these earlier studies, the main objective of our study has been to address the regional distribution of snow accumulation on Spitsbergen. In addition to increasing our knowledge of regional snow accumulation patterns, accumulation data from our study can contribute significantly to studies dealing with (1) water balance; (2) biology (e.g., length of growth season or food availability for reindeers); (3) surface energy balance; (4) climate (e.g., regional modelling), and (5) active layer research.

The scope of this study is limited to regional distribution of winter accumulation on Spitsergen, Svalbard. More measurements are needed to test whether or not our method represents the actual pattern in snow accumulation and whether the winter season of 1996/97 can be considered a representative winter season. Some measure of how representative the 1996/97 winter was can be found by comparing winter precipitation (October 


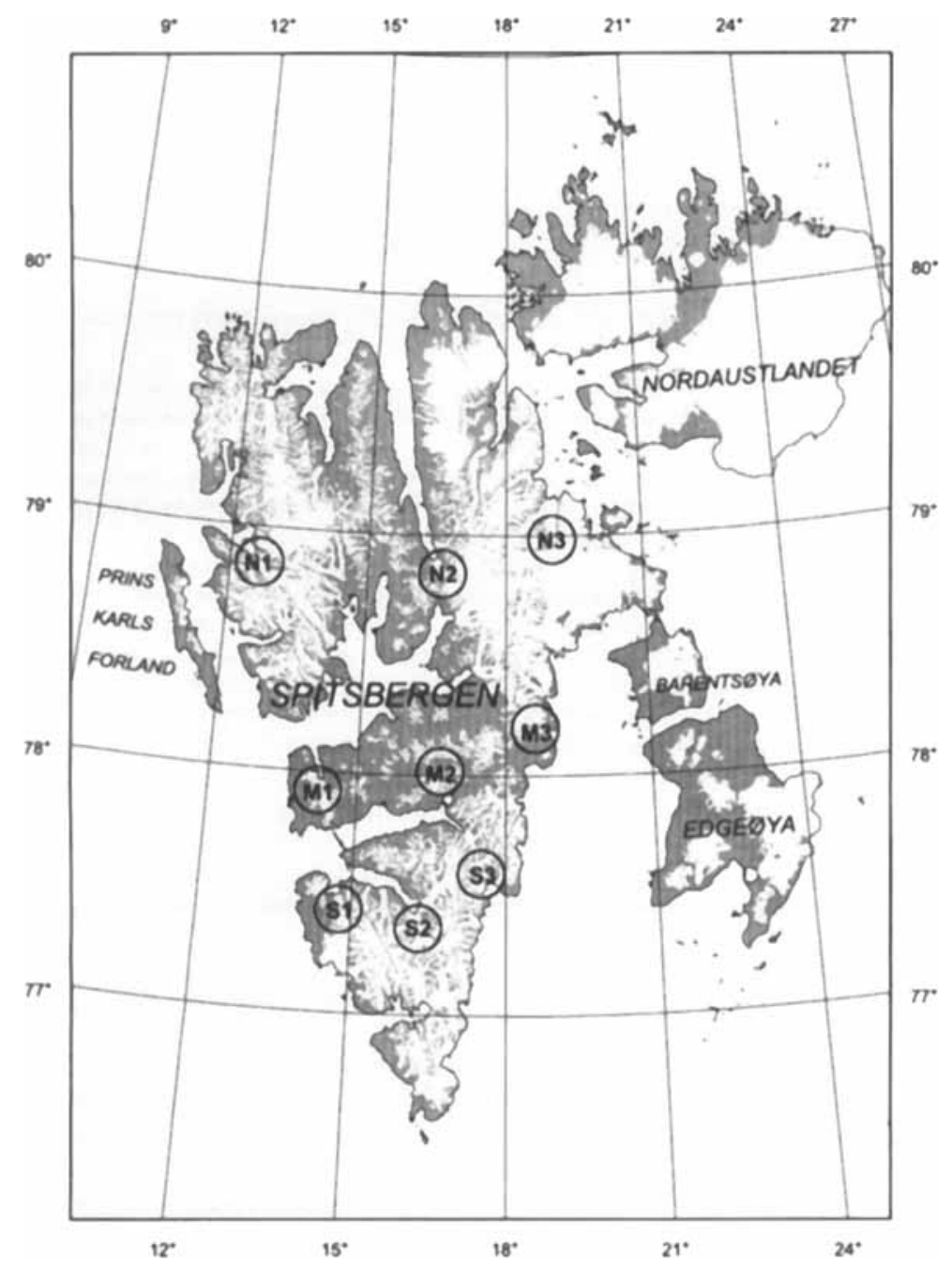

Fig. 1. The Svalbard archipelago. Measurement areas where snow accumulation measurements were collected are indicated on three west-toeast transects. through May) for this particular accumulation year with the average precipitation for a 30 -year period (Førland et al. 1997a). Such a comparison shows that winter precipitation in 1996/97 was $94.1 \%$ of the 1961-90 normal for Svalbard Airport (due north of area M2 in Fig. 1). The corresponding number for Ny-Älesund (within area N1 in Fig. 1) was $69.8 \%$. This indicates that the winter accumulation in $1996 / 97$ at these two locations was lower than the 30-year average, with lowest values in northwestern Spitsbergen. Further field studies will aim at collecting snow accumulation data from larger areas of Svalbard.

\section{Study area}

Svalbard comprises a group of islands located between latitudes $76^{\circ}$ and $81^{\circ} \mathrm{N}$ and between longitudes $10^{\circ}$ and $35^{\circ} \mathrm{E}$ (Fig. 1). The total area of the archipelago is about $63,000 \mathrm{~km}^{2}, 60 \%$ of which is covered by glaciers. Non-glaciated areas have continuous permafrost which varies in depth from less than $100 \mathrm{~m}$ close to the coast to more than $500 \mathrm{~m}$ in mountainous areas (Liest $\varnothing 1$ 1977).

The climate of Svalbard is strongly influenced by the North Atlantic Current, a branch of the Gulf Stream (Hisdal 1976). The average annual 
temperature along the western coast of Spitsbergen is about $-6^{\circ} \mathrm{C}$, while further inland it is slightly colder with a more continental climate. The average temperature at Isfjord Radio on the western coast is $+4.7^{\circ} \mathrm{C}$ for the warmest month (July) and $-11.7^{\circ} \mathrm{C}$ for the coldest (March).

Along the western coast of Spitsbergen most of the precipitation occurs in connection with cyclones moving in from the SW-NW sector (Hanssen-Bauer et al. 1990). However, because of the frequent easterly winds produced by the low pressure systems passing through the Barents Sea, the highest precipitation occurs in the easterncentral part of the archipelago, i.e. at the eastern coast of Spitsbergen (Hisdal 1976). Glaciated areas exist along both the western and eastern coasts indicating a accumulation-temperature regime favourable for the formation of glaciers (Fig. 1). Yearly average accumulation is measured to be somewhat less than $400 \mathrm{~mm}$ in western Spitsbergen. However, because of the very sparse network of meteorological stations, there is some uncertainty associated with the estimated regional distribution of accumulation (Sand \& Winthe! 1992). Non-glaciated areas defined as polar deserts are found in the northern parts of Spitsbergen (Hisdal 1976). These polar deserts are also reflected in the ELA which ranges from around $200 \mathrm{~m}$ a.s.l. in southeast Spitsbergen to more than $800 \mathrm{~m}$ in the central-northern Spitsbergen, indicating a more continental type of climate in the latter region (Hagen et al. 1993).

Fig. 1 shows the nine glaciated areas from which data have been collected for this paper. Snow accumulation was measured and recorded by longitudinal and transversal radar profiling together with manual measuring of snow depth, snow temperature, snow density, and snow stratigraphy from snow pits. Radar profiles span elevations between 0 and $1000 \mathrm{~m}$ a.s.l. The southernmost locations (S1-S3) were visited during 6-9 May, the middle locations (M1-M3) during 1215 May, and finally the northernmost locations (N1-N3) during 20-22 May 1997.

\section{Data collection and methods}

The measuring strategy was designed to address the three assumptions below. Firstly, low pressure systems which transport humid and relatively warm air masses towards the island in winter are associated with dominant SW-NW and easterly wind directions (Hisdal 1976). Thus, we expected to find higher accumulation rates along the coasts than in the central parts. We also wanted to design our measurement programme so that any southnorthwards trends in accumulation could be detected.

Secondly, snow-depth profiling was employed on wide glaciers to eliminate the influence of snowdrift formation which occurs because of the varying topography. We assumed that glaciers wider than $1 \mathrm{~km}$ were of sufficient size to allow the snow transport to reach equilibrium or steady-stateconditions. This assumption is in accordance with model work on blowing snow by Pomeroy et al. (1993) and Liston \& Sturm (in press) where a $500 \mathrm{~m}$ equilibrium fetch distance (f) has been used. All of the data in the present study were collected on glaciers wider than $1 \mathrm{~km}$.

Obviously, direct erosion, direct sublimation, and sublimation of suspended snow can remove snow. Measurements from Antarctica indicate an upper limit of sublimation of suspended snow of about $15 \mathrm{~cm}$ water equivalent per year and comparable amounts of snow removal through direct erosion and direct sublimation (Van den Broeke pers. commun.). Due to a different temperature regime and wind speeds on Svalbard, these numbers cannot be directly compared. Takeuchi et al. (1995) measured direct sublimation in early June 1993 in Ny-Ålesund, Svalbard, and found typical values to lie between 0.01 to $0.03 \mathrm{~mm} / \mathrm{h}$ during a 14 day dry snow period. These numbers give a total sublimation of $7-20 \mathrm{~cm} / \mathrm{y}$ for 273 days (October through June). The total sublimation is probably less because of smaller sublimation rates in winter. It seems clear however, that due to snow removal mechanisms, our measurements may underestimate the amount of precipitated snow. Even so, since this study primarily seeks to investigate the regional distribution of winter accumulation, we have chosen to omit calculating the amount and variability of snow removal/snow deposition at this stage. Nevertheless, we have attempted to reduce the local effect of snow removal/deposition by wind, by carrying out the measurements on wide, mostly gently sloping glaciers as described above.

Our third assumption was based on obtaining measurements of the accumulation-elevation gradient by spanning altitudes from sea level to about $1000 \mathrm{~m}$ a.s.l. Earlier work by Hagen and Liestø] (1990) indicates a gradient of about $100 \mathrm{~mm}$ w.eq.l $100 \mathrm{~m}$ for Austre Brøggerbreen glacier in the 


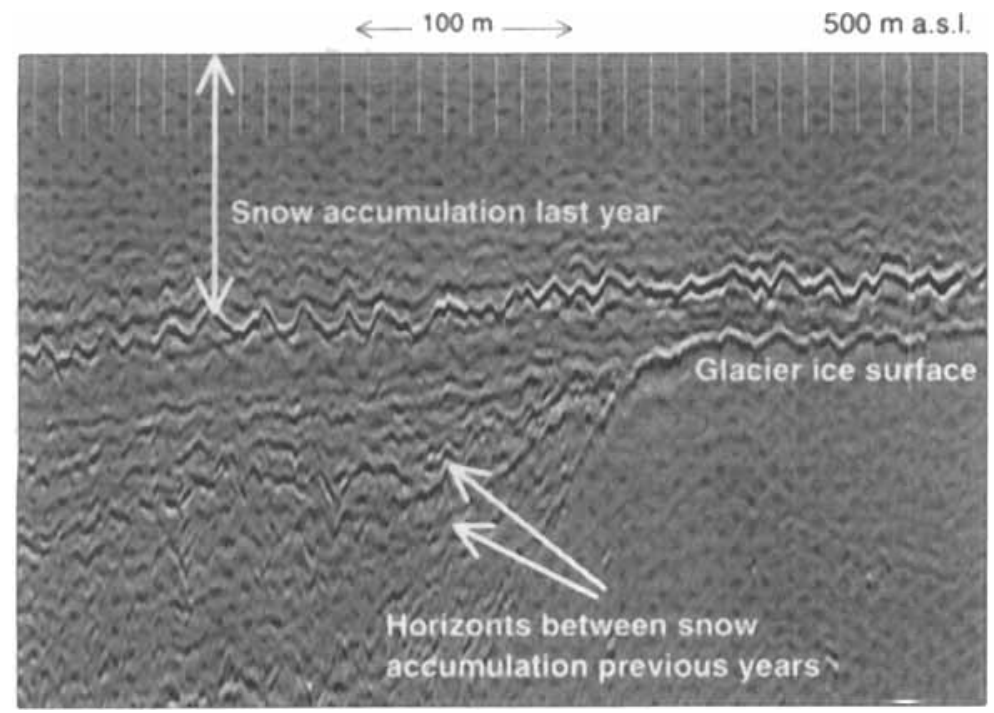

Fig. 2. GSSI SIR-2 System radar profile from Grønfjordbreen (measurement area M1, Fig. 1). The upper (almost horizontal) strong reflecting layer is the boundary between last years accumulated snow and the snow from the previous summer (decreasing altitudes towards the right).

Bayelva basin, whereas Tveit and Killingtveit (1996) report gradients of $85 \mathrm{~mm} / 100 \mathrm{~m}, 57 \mathrm{~mm} /$ $100 \mathrm{~m}, 20 \mathrm{~mm} / 100 \mathrm{~m}$, and $85 \mathrm{~mm} / 100 \mathrm{~m}$ for 1991 , 1992, 1993, and 1994, respectively, from the Endalen basin. Our objectives were to extend the existing data set and to compare our results with earlier work.

\section{Radar measurements}

Snow depth was measured with two different ground-penetrating radar systems. On glaciers in the southern transect, a PulsEKKO radar with a $450 \mathrm{MHz}$ antenna was used. A GSSI SIR System-2 radar with a $500 \mathrm{MHz}$ antenna was used for the middle and northern transects.

Impulse radar is characterised by the sending of very short, broadband signals. It can therefore determine short ranges with high resolution. The radar detects interfaces of layers with different dielectric characteristics. The two-way travel time (TWT), i.e. the time from the signal is transmitted until it is received by the antenna, indicates the depth to the reflector.

The delay of an electromagnetic wave travelling through a snow pack is proportional to the snow depth and inversely proportional to the average velocity of the wave. The average velocity is determined by the dielectric constant of the snow (Eq. 1) which in turn is related to the average density. In dry media, bulk density primarily influences the dielectric constant. Under partially saturated or saturated conditions, the dielectric constant is mainly determined by the liquid-water content. The dielectric constant for dry snow normally ranges from about 1.5 to 2.5 , while values up to 7 are found for saturated snow. In firn and glacier ice, the value is about 4. Fig. 2 shows a section from the radar profile at Grønfjordbreen (area M1 in Fig. 1). The upper (almost horizontal) strong reflecting layer is the boundary between last year's accumulated snow and snow from the previous summer. The second strong reflective layer observed at the $500 \mathrm{~m}$ a.s.l. altitude is probably blue glacier ice that was exposed two years earlier. These two reflection horizons merge at lower altitudes (beyond the right edge of Fig. 2) where the border between the blue ice and the snow existed the previous summer. The $500 \mathrm{~m}$ a.s.l. altitude is marked as a vertical white line and corresponds in this case approximately with the location of the equilibrium line. The ELA is located where the glacier ice surface 'dives' down under several layers of snow accumulated through earlier years (Fig. 2).

The wave propagation speed can be calculated as follows:

$$
V=c / \sqrt{\epsilon}_{r}
$$

where: $V=$ wave propagation speed

$c=$ speed of light in vacuum $(0.3 \mathrm{~m} / \mathrm{ns})$

$\epsilon_{r}=$ relative dielectric constant 
Table 1. Snow-equivalents in $\mathrm{mm}$ and snow density $\left(\mathrm{g} / \mathrm{cm}^{3}\right)$ as a function of altitude for all nine measurement areas (Fig. 1).

\begin{tabular}{|c|c|c|c|c|c|c|c|c|c|}
\hline$m$ a.s.l. & S1 & S2 & S3 & M1 & M2 & M3 & N1 & $\mathrm{N} 2$ & N3 \\
\hline 100 & $431 / 0.390$ & $505 / 0.359$ & $488 / 0.351$ & $523 / 0.418$ & & $697 / 0.400$ & & & \\
\hline 200 & $542 / 0.390$ & $575 / 0.359$ & $622 / 0.351$ & $471 / 0.418$ & $306 / 0.343$ & $896 / 0.400$ & $195 / 0.341$ & & \\
\hline 300 & $651 / 0.385$ & $777 / 0.359$ & $1082 / 0.351$ & $454 / 0.309$ & $334 / 0.343$ & $975 / 0.400$ & $240 / 0.341$ & & $678 / 0.388$ \\
\hline 400 & $757 / 0.385$ & $1212 / 0.407$ & $1163 / 0 / 390$ & $500 / 0.309$ & $466 / 0.343$ & $1060 / 0.400$ & $362 / 0.341$ & & $762 / 0.388$ \\
\hline 500 & $927 / 0.385$ & & $1241 / 0.390$ & $694 / 0.309$ & $594 / 0.392$ & $1079 / 0.400$ & $537 / 0.385$ & & $701 / 0.380$ \\
\hline 600 & $1470 / 0.448$ & & & & $702 / 0.392$ & $1073 / 0.400$ & $630 / 0.385$ & $467 / 0.312$ & $769 / 0.380$ \\
\hline 700 & & & & & $80 \mathrm{~L} / 0.392$ & $657 / 0.400$ & $721 / 0.385$ & $349 / 0.312$ & $729 / 0.380$ \\
\hline 800 & & & & & & & $838 / 0.385$ & $585 / 0.312$ & $613 / 0.380$ \\
\hline 900 & & & & & & & & $771 / 0.312$ & $754 / 0.380$ \\
\hline 1000 & & & & & & & & & $709 / 0.380$ \\
\hline 1100 & & & & & & & & $646 / 0.312$ & $773 / 0.380$ \\
\hline 1200 & & & & & & & & $563 / 0.312$ & \\
\hline
\end{tabular}

At each measurement area (Fig. 1), at both low and high altitudes, manual snow depth measurements were taken every $5 \mathrm{~m}$ over a distance of 100 $m$ as a check of snow depths measured by the radar. In total, 260 manual snow depth measurements for comparison with radar measurements were taken. In addition, temperature, density, and stratigraphy of the snow pack were measured in snow pits. All measurements showed snow temperatures below zero degrees, indicating dry conditions. Snow densities varied from 0.312 to $0.448 \mathrm{~g} / \mathrm{cm}^{3}$, averaging to $0.371 \mathrm{~g} / \mathrm{cm}^{3}$. According to the model of Loyenga (Glen \& Paren 1975), this should give a dielectric constant close to 1.7. Measured snow water-equivalents (in $\mathrm{mm}$ ) and density as a function of altitude for all nine areas are presented in Table 1 .

Snow water-equivalent can be calculated from the TWT measured by the radar for a given dielectric constant when snow density is known. For each of the $100 \mathrm{~m}$ control lines where manual snow depth measurements were taken, a dielectric constant representative for the snow conditions at that location was chosen, thus resulting in the best agreement between manual measured snow waterequivalents (in $\mathrm{mm}$ ) and radar measurements. The average value of the dielectric constant for all measurements was 1.92. When comparing radar measurements with 260 corresponding manual control measurements, the radar measurements produced average values that were $3.9 \%$ higher (in $\mathrm{mm}$ water eq.) than the manual ones.

\section{Results}

\section{Effects of topography}

Fig. 3 shows the Slakbreen glacier located in measurement area M2 (Fig. 1) together with one longitudinal profile and three cross-profiles where radar measurements were taken. The longitudinal profile ranges from $144 \mathrm{~m}$ a.s.l. to $788 \mathrm{~m}$ a.s.l. whereas the cross-profiles follow the 300,500 , and $650 \mathrm{~m}$ a.s.l. contour lines.

Fig. 4 illustrates how snow depth varies with distance for the three transversal profiles. With attention to the $500 \mathrm{~m}$ a.s.l. profile, it is clearly seen that at both ends of the profile (i.e. about 300 metres on each side of the glacier) the snow pack is deeper than in the middle part of the profile. This is especially obvious for the north-eastern end of the cross profile. This can not be seen as clearly for the profiles following the 300 and $650 \mathrm{~m}$ a.s.l. contour lines. Nevertheless, both profiles have lower snow depths for the first 200 metres, which can be attributed to wind erosion. The last 250 metres of the cross profile at the $300 \mathrm{~m}$ a.s.l. contour line shows again the effect of increasing snow depths at the edge of the glacier, possibly due to snow drift formation.

Fig. 5 shows snow water-equivalent as a function of elevation for the longitudinal profile of Slakbreen. There is a clear correlation between elevation and snow depth (in $\mathrm{mm}$ water eq.). Large snow water-equivalents above 700 metres are most likely due to snow drift formation. This snow drift persists approximately 400 metres. This portion of the profile corresponds to the location where the profile enters the main part of the Slakbreen glacier after having covered a steep feeding glacier (Fig. 3). It is assumed that this snow drift forms with the change of slope, i.e. when wind speed decreases when it enters the flatter Slakbreen. Consequently, snow is deposited until steady-state conditions are reached, in this case after about 400 metres. 


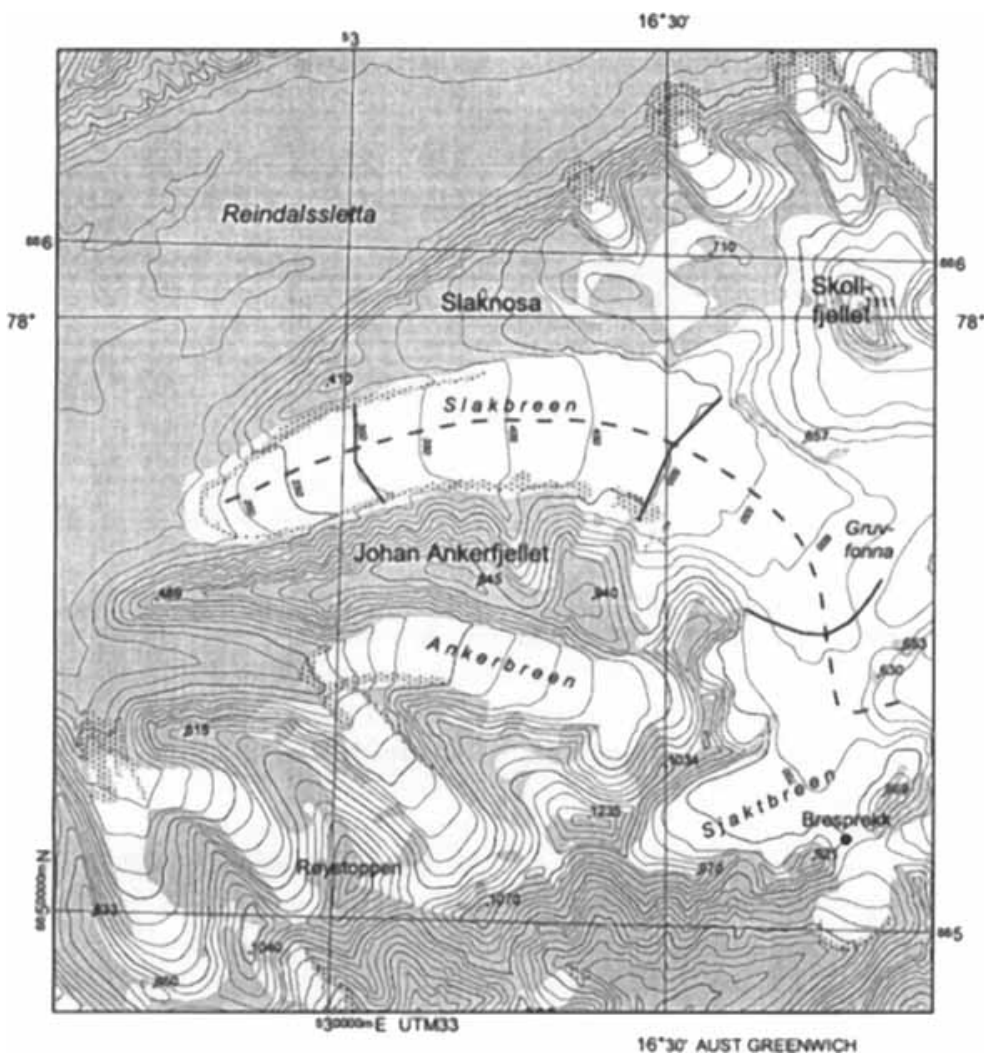

Fig. 3. Locations of longitudinal $(-\ldots)$ and transversal (-) radar profiles taken on the glacier, Slakbreen (area M2, Fig. 1).
The examples above support our second hypothesis that the effect of snowdrift formation is eliminated when the measuring is performed on wide glaciers and is in accordance with Pomeroy et al. (1993).

\section{Elevation gradient}

If the upper $\mathrm{km}$ of the longitudinal profile shown in Fig. 5 is omitted because of the snowdrift formation described above, the snow waterequivalent increases from about $300 \mathrm{~mm}$ at 200 $\mathrm{m}$ a.s.l. to about $630 \mathrm{~mm}$ at $600 \mathrm{~m}$ a.s.l. The average densities at these elevations were measured to be $0.343 \mathrm{~g} / \mathrm{cm}^{3}$ and $0.392 \mathrm{~g} / \mathrm{cm}^{3}$. The snow waterequivalent gradient as a function of elevation is calculated to be $88.3 \mathrm{~mm} / 100 \mathrm{~m}(144<\mathrm{x}<688)$ (Fig. 6). For comparison, Tveit and Killingtveit (1996) report gradients of water equivalent with elevation to be $85 \mathrm{~mm} / 100 \mathrm{~m}, 57 \mathrm{~mm} / 100 \mathrm{~m}, 20 \mathrm{~mm} /$ $100 \mathrm{~m}$, and $85 \mathrm{~mm} / 100 \mathrm{~m}$ for $1991,1992,1993$, and
1994, respectively, from the Endalen catchment about $30 \mathrm{~km}$ northwest of the Slakbreen glacier.

When considering the whole data set, the snow water-equivalent gradients as a function of elevation for the southern glaciers are $119 \mathrm{~mm} / 100 \mathrm{~m}$ (west), $237 \mathrm{~mm} / 100 \mathrm{~m}$ (central), and $204 \mathrm{~mm} / 100 \mathrm{~m}$ (east). For the glaciers in the middle transect (areas M1-M3) the corresponding numbers are $64 \mathrm{~mm} /$ $100 \mathrm{~m}, 91 \mathrm{~mm} / 100 \mathrm{~m}$, and $94 \mathrm{~mm} / 100 \mathrm{~m}$. Finally, for the northern glaciers the figures are $111 \mathrm{~mm} / 100 \mathrm{~m}$, $11 \mathrm{~mm} / 100 \mathrm{~m}$, and $3 \mathrm{~mm} / 100 \mathrm{~m}$. Fig. 6 is a plot of the overall data set where snow water-equivalent (y) is plotted against altitude $(\mathrm{x})$. It should be noted that the gradients are calculated for different height levels (see Table 1), and thus are not directly comparable. Also, a decrease in accumulation occurs at the highest elevation in areas M3 and N2 (Table 1), probably because of snow drift.

\section{South-north gradient}

In Figs. 7 and 8, the snow water equivalent for the 
glaciers located on the western coast (areas S1, $\mathrm{M} 1$, and N1 - Fig. 1) and on the eastern coast (areas S3, M3, and N3 - Fig. 1) respectively, are showing the south to north distribution of accumulated snow. When measurements made at $400 \mathrm{~m}$ a.s.l. at the western coast were compared, the average water equivalent for the southern glaciers is $757 \mathrm{~mm}$ while the corresponding number for the northern glaciers is $393 \mathrm{~mm}$, i.e. a decrease of $48 \%$ over a distance of $170 \mathrm{~km}$. Similar figures for the eastern coast are $1163 \mathrm{~mm}$ and $762 \mathrm{~mm}$, i.e. a decrease of about $34 \%$.

By comparing all measurements from same elevations, the average decrease from south to north on the western coast is $55 \%$ while it is $40 \%$ on the east coast. Further, Table 2 presents the relationship between snow water-equivalent numbers for all measurement areas.

\section{West-east gradient}

Fig. 9 illustrates snow accumulation in water equivalent for the northern glaciers. The overall picture is that a minimum of accumulated snow occurs at the central (inland) glaciers. This minimum appears as well for the glaciers in the middle transect, while no such trend appears along the southern transect.

One way of presenting this data is by calculating gradients of snow depth by distance (or per degree longitude). The following gradients have been computed: $\mathrm{S} 1-\mathrm{S} 2$ : $+134 \mathrm{~mm} /$ degree east (where $\mathrm{S} 1-\mathrm{S} 2$ is the gradient between area $\mathrm{S} 1$ and area $\mathrm{S} 2$ ); $\mathrm{S} 2-\mathrm{S} 3$ : + $171 \mathrm{~mm} /$ degree east; $\mathrm{M} 1-\mathrm{M} 2$ : $-78 \mathrm{~mm} /$ degree east; $\mathbf{M} 2-\mathbf{M} 3:+220 \mathrm{~mm} /$ degree east; N1-N2: $-76 \mathrm{~mm} /$ degree east; and N2-N3: $+150 \mathrm{~mm} /$ degree east. This shows that there is a clear tendency of low accumulation rates in the central parts of the two northernmost transects, while the accumulation rates in the south increase continuously from west to east.

\section{Discussion and conclusions}

The georadar profiling method reproduces snow thickness measured on glaciers very well when the radar signal is calibrated with manual depth measurements. Winter accumulation for about nine months has been measured over large areas of similar geography. Because this method provides useful data on regional snow distribution over large areas, it can be a valuable tool in monitoring future changes in snow accumulation.

However, additional snow depth surveys are needed in order to determine if our measurements are representative of the snow accumulation in adjacent areas. Although we have measured the snow depth accurately, the chosen profiles may not reflect the spatial snow accumulation outside our measured transect areas. A lack of correspondence of our observations with the more general snow distribution patterns can perhaps be accounted for by the following factors: (1) precipitation is generally higher on glaciers because of an orographic effect (Førland et al. 1997b); (2) prevailing weather systems give higher/lower precipitation rates in certain (local) areas; (3) the micro-/mesoscale topography causes the formation of snowdrifts (i.e. our hypothesis about steady-state conditions on wide glaciers may not be valid); (4) measuring at glaciers provides little data from low elevation, thus our elevation gradients may be biased; (5) the presence of katabatic winds influences accumulation on different glaciers to different degrees; and (6) snow removal by sublimation varies spatially.

Because of the above-mentioned spatial variability on Spitsbergen, we emphasise that the measured accumulation gradients may not be representative of winter accumulation trends for the entire area. However, we believe that the data set provides new insight into the regional-scale accumulation patterns on Spitsbergen. Our field campaigns in coming years will aim at addressing the foregoing uncertainties regarding representation. In addition, data will be collected from larger areas of the Svalbard archipelago. The conclusions drawn below are based on the existing data set and the above discussion concerning possible error sources.

Generally, the accumulation is higher on the eastern coast than on the western, indicating that more winter accumulation comes with easterly winds than with westerly winds. Snow accumulation gradients are calculated to be in the order of $49 \%, 42 \%$ and $38 \%$ increase from west to east for locations in the north, middle, and south, respectively. A minimum is clearly seen for the central (inland) glaciers in the middle and northern transect. The minimum is probably more pronounced in the north than is reflected by our data because the central measuring area (i.e. area N2 - Fig. 1) is off-set somewhat easterly and does not capture the areas of lowest accumulation. A 


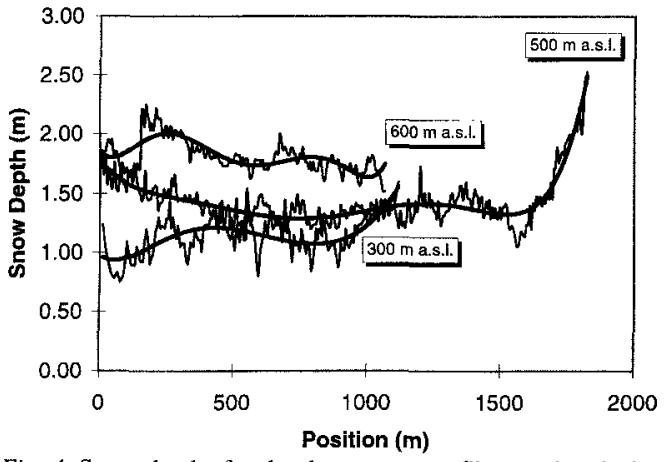

Fig. 4. Snow depths for the three cross profiles on the glacier, Slakbreen, measured by radar at 300,500 , and $650 \mathrm{~m}$ a.s. 1 .

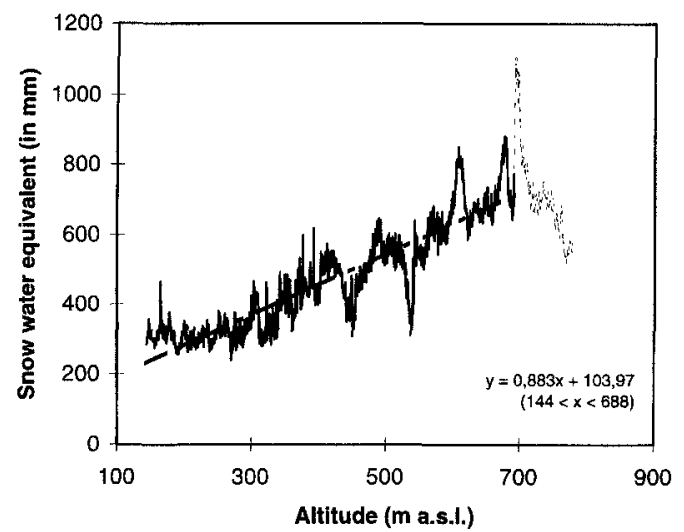

Fig. 5. Snow water-equivalent (y) plotted against altitude (144 $<\mathrm{x}<778$ ) for the longitudinal profile on the glacier, Slakbreen (Fig. 5). The snow water-equivalent gradient as a function of elevation $(144<\mathrm{x}<688)$ is $88.3 \mathrm{~mm} / 100 \mathrm{~m}$ (see text for discussion).

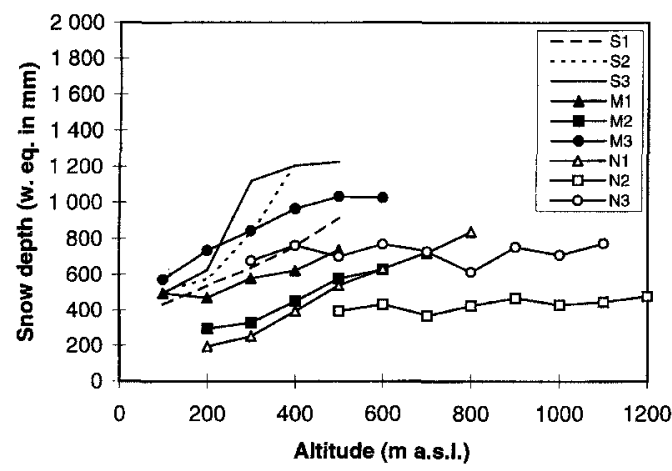

Fig. 6. Snow water-equivalent (y) plotted against elevation $(\mathrm{x})$ for all glaciers measured. The following linear gradients are calculated: S1: $y=1.1887 x+298.55(100<x<500)$, S2: $y=$ $2.3741 x+186.65(100<x<400), S 3: y=2.0395 x+321.32$ $(100<\mathrm{x}<500), \mathrm{M} 1: \mathrm{y}=0.6408 \mathrm{x}+387.50(100<\mathrm{x}<500), \mathrm{M} 2$ : $y=0.9149 x+88.86(200<x<700), M 3: y=0.9352 x+534.06$ $(100<x<600), N 1: y=1.1102 x-45.84(200<x<800), N 2: y$ $=0.1061 \mathrm{x}+338.61(500<\mathrm{x}<1200), \mathrm{N} 3: \mathrm{y}=0.0289 \mathrm{x}+700.66$ $(300<\mathrm{x}<1100)$.

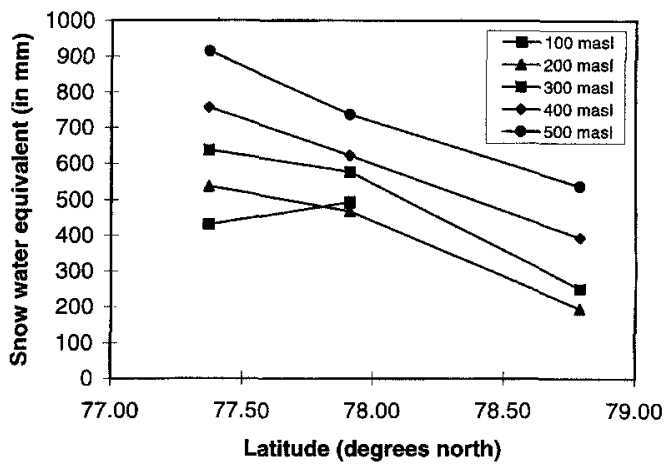

Fig. 7. The south-to-north trend on the western coast (i.e., areas S1, M1 and N1 - Fig. 1) expressed as snow water-equivalent (in $\mathrm{mm}$ ) for a range of elevations.

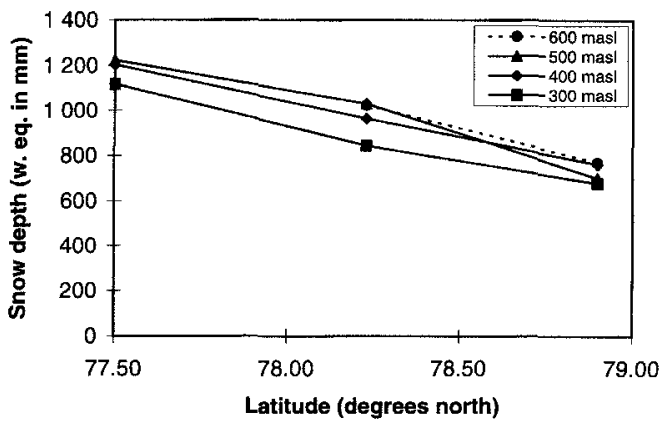

Fig. 8. The south-to-north trend on the eastern coast (i.e., areas S3, M3 and N3 - Fig. 1) expressed as snow water-equivalent (in $\mathrm{mm}$ ) for a range of elevations.

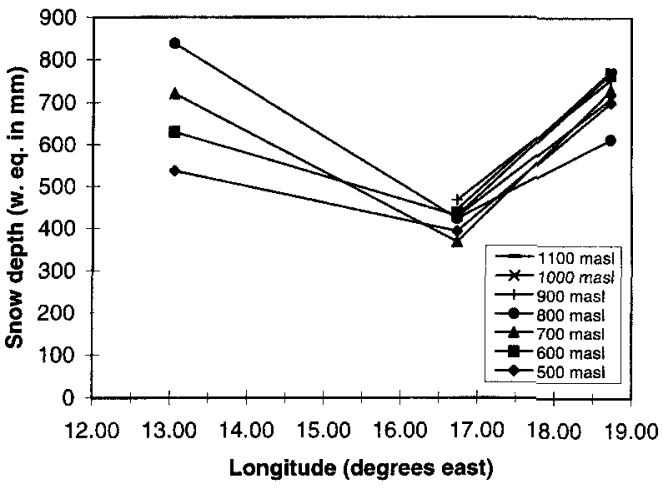

Fig. 9. The west-to-east trend in snow water-equivalent for the northern glaciers at various elevations. The minimum in accumulated snow at the central glaciers is clearly seen. 
Table 2. The ratio between snow water-equivalent for different measurement areas is presented for given altitudes. For example, $\mathrm{S} 3 / \mathrm{S} 1=113 \%$ at an altitude of 100 metres means that glaciers in area $\mathrm{S} 3$ have $113 \%$ more snow (in mm water eq.) than glaciers in area $\mathrm{S} 1$ at this altitude. Furthermore, the average number represents the snow water-equivalent ratio between glaciers in two different areas, for all altitude ranges that appear in both areas.

\begin{tabular}{|c|c|c|c|c|c|c|c|c|c|}
\hline Altitude & $S 3 / S 1$ & $\mathrm{~S} 2 / \mathrm{S} 1$ & $\mathrm{~S} 3 / \mathrm{S} 2$ & M3/M1 & $\mathrm{M} 2 / \mathrm{M} 1$ & $\mathrm{M} 3 / \mathrm{M} 2$ & $\mathrm{~N} 3 / \mathrm{N} 1$ & $\mathrm{~N} 2 / \mathrm{N} 1$ & $\mathrm{~N} 3 / \mathrm{N} 2$ \\
\hline 100 & $113 \%$ & $117 \%$ & $97 \%$ & $109 \%$ & & & & & \\
\hline 200 & $115 \%$ & $106 \%$ & $108 \%$ & $156 \%$ & $65 \%$ & $240 \%$ & & & \\
\hline 300 & $176 \%$ & $127 \%$ & $139 \%$ & $143 \%$ & $57 \%$ & $252 \%$ & $271 \%$ & & \\
\hline 400 & $154 \%$ & $160 \%$ & $96 \%$ & $155 \%$ & $75 \%$ & $207 \%$ & $194 \%$ & & \\
\hline 500 & $134 \%$ & & & $148 \%$ & $86 \%$ & $173 \%$ & $130 \%$ & $73 \%$ & $178 \%$ \\
\hline 600 & & & & & & $146 \%$ & $122 \%$ & $68 \%$ & $179 \%$ \\
\hline 700 & & & & & & & $101 \%$ & $51 \%$ & $199 \%$ \\
\hline 800 & & & & & & & $73 \%$ & $50 \%$ & $145 \%$ \\
\hline 900 & & & & & & & & & $161 \%$ \\
\hline 1000 & & & & & & & & & $166 \%$ \\
\hline 1100 & & & & & & & & & $174 \%$ \\
\hline Average & $138 \%$ & $128 \%$ & $108 \%$ & $142 \%$ & $71 \%$ & $204 \%$ & $149 \%$ & $61 \%$ & $172 \%$ \\
\hline $\begin{array}{l}\text { Altitude } \\
100\end{array}$ & $\mathrm{~N} 1 / \mathrm{S} 1$ & $\mathrm{~N} 2 / \mathrm{S} 2$ & $\mathrm{~N} 3 / \mathrm{S} 3$ & $\begin{array}{c}\mathrm{M} 1 / \mathrm{S} 1 \\
121 \%\end{array}$ & $\mathbf{M} 2 / \mathbf{S} 2$ & $\begin{array}{c}\mathrm{M} 3 / \mathrm{S} 3 \\
117 \%\end{array}$ & Nl/Ml & $\mathrm{N} 2 / \mathrm{M} 2$ & N3/M3 \\
\hline 200 & $36 \%$ & & & $87 \%$ & $53 \%$ & $118 \%$ & $41 \%$ & & \\
\hline 300 & $38 \%$ & & $59 \%$ & $91 \%$ & $40 \%$ & $74 \%$ & $42 \%$ & & $80 \%$ \\
\hline 400 & $52 \%$ & & $66 \%$ & $82 \%$ & $38 \%$ & $83 \%$ & $63 \%$ & & $79 \%$ \\
\hline 500 & $58 \%$ & & $56 \%$ & $75 \%$ & & $83 \%$ & $77 \%$ & $66 \%$ & $68 \%$ \\
\hline 600 & $43 \%$ & & & & & & & $61 \%$ & $75 \%$ \\
\hline 700 & & & & & & & & $46 \%$ & \\
\hline Average & $45 \%$ & & $60 \%$ & $91 \%$ & $44 \%$ & $95 \%$ & $56 \%$ & $58 \%$ & $76 \%$ \\
\hline
\end{tabular}

similar minimum is not seen in the southern transect. This may be accounted for by the fact that the weather conditions that mainly bring precipitation over Spitsbergen come with winds from westerly and easterly directions. Since the island is narrow in the south, precipitation from both prevailing directions tends to reach the inland parts of the island, thus not producing a minimum (or 'snow shadow') in accumulation. A more continental climate with less precipitation exists for the central (inland) parts where the island widens towards the north.

The south-north gradient in snow accumulation is clearly seen in the data set with decreasing accumulation from south to north. On average, the decrease from the southern locations to the northern locations over a distance less than 200 $\mathrm{km}$ is calculated to be about $55 \%$ at the western coast and around $40 \%$ at the eastern coast.

The snow accumulation-elevation gradient varies greatly, ranging from between $3 \mathrm{~mm} / 100$ $\mathrm{m}$ (area N3) to $237 \mathrm{~mm} / 100 \mathrm{~m}$ (area S2). As stated earlier, a general explanation for these large variations can be that gradients are calculated for different elevation ranges in different areas (Table 1). More specifically, Nathorstbreen glacier (area
S2) is located in the inner part of Van Keulenfjorden. Air masses that follow the fjord during westerly winds may deposit snow rapidly after reaching the Nathorstbreen where the lifting and cooling of air masses are assumed to occur. An additional explanation for the large gradients in this area is that Nathorstbreen, in agreement with our measurements, has a northwest-to-southeast direction. Therefore, there will be an effect from the west-toeast gradient that is superimposed upon the elevation gradient. With respect to area S3, the high gradient $(204 \mathrm{~mm} / 100 \mathrm{~m})$ may be explained by the coastal location of the glacier, Strongbreen, where the measurements were taken. The calving front of this glacier empties directly into the sea, and the data show that the large gradient is mainly caused by very large gradients between sea level and $300 \mathrm{~m}$ a.s.l. Thus, we believe that humid air masses following south-easterly and easterly winds will deposit snow shortly after reaching the eastern coast in this area. A possible explanation for the very low gradient found at area $\mathrm{N} 3(3 \mathrm{~mm} / 100 \mathrm{~m})$ is that the elevation gradient is counterbalanced by the coast-inland gradient because of the orientation of the glacier. Area $\mathrm{N} 2(11 \mathrm{~mm} / 100 \mathrm{~m})$ is surrounded by areas of very low accumulation. This area is sheltered from 
'precipitation-bearing' air streams (Hisdal 1976). As the precipitation intensities are very low, this may be the reason for the low values of elevation gradients measured here.

The remaining glaciers show snow accumulation-elevation gradients from $64 \mathrm{~mm} / 100 \mathrm{~m}$ to 119 $\mathrm{mm} / 100 \mathrm{~m}$, with an average of $96 \mathrm{~mm} / 100 \mathrm{~m}$. The average of all measurements is $104 \mathrm{~mm} / 100 \mathrm{~m}$.

Acknowledgements. - We would like to thank the staff and students at the University Courses on Svalbard (UNIS) for their kind and professional assistance during the field campaigns, and the Norwegian Polar Institute for providing vital field equipment. SINTEF and UNIS are thanked for kindly lending us the radars used in this study. G. Anker at the Norwegian Potar Institute is acknowledged for providing us with Figs. 1 and 3.

\section{References}

Førland, E. J., Hanssen-Bauer, I. \& Nordli, P. Ø. 1997a: Climate statistics \& longterm series of temperature and precipitation at Svalbard and Jan Mayen. Norwegian Meteorological Institute. DNMI-report No. 21/97. 72 pp.

Førland, E. J., Hanssen-Bauer, I. \& Nordli, P. Ø. 1997b: Orographic precipitation at the glacier Austre Brøggerbreen, Svalbard. Norwegian Meteorological Institute. DNMI-report No. 02/97. 45 pp.

Glen, I. W. \& Paren, I. G. 1975: The electrical properties of snow and ice. J. Glaciol. 15(73), 15-37.

Hagen. J. O, 1996: Svalbard. In: Jania, J. \& Hagen. J. O. (eds.): Mass balance of Arctic Glaciers. IASC Report No. 5.62 pp.

Hagen, J. O. \& Liestøl, O. 1987: Glacier mass balance investigations in the balance years 1984-1985 and 19851986. Polar Res. 5, 261-265.

Hagen, J. O. \& Liestøl, O. 1990: Long term glacier mass balance investigations in Svalbard 1950-1988. Ann. Glaciol. 14, 102-106.
Hagen, J. O., Liestøl, O., Roland, E. \& Jørgensen, T. 1993: Glacier atlas of Svalbard and Jan Mayen. Norsk Polarinstitutts Meddelelser No.129. $168 \mathrm{pp}$.

Hanssen-Bauer, I., Kristensen Solås, M. \& Steffensen, E. L. 1990: The climate of Spitsbergen. Norwegian Meteorological Institute. DNMI-report No. 39/90. $40 \mathrm{pp}$.

Hisdal, V. 1976: Geography of Svalbard (first ed.). Norwegian Polar Research Institute, Oslo. 75 pp.

Jania, J. 1994: Field investigations during the glaciological expeditions to Spitsbergen in the period of 1992-1994. Interim report. University of Silesia, Katowice. 40 pp.

Killingtveit, A., Petterson, L. E. \& Sand, K. 1996: Water balance studies at Spitsbergen, Svalbard. Pp. 77-94 in Sand, K. \& Killingtveit, $\AA$. (eds.): Proceedings of the $10 \mathrm{th}$ Northern Research Basins Symposium and Workshop, Spitsbergen, Norway.

Krenke, A. N., Korjakin, V. S. \& Tareeva, A. M. 1986: Accumulation of snow at the height of the feeding limit of the glaciers of Spitsbergen (In Russian). Data of Glaciological Studies, Publication No. 56, 90-93.

Lefauconnier, B., Hagen, J. O., Pinglot, J. F. \& Pourchet, M. 1994: Mass balance estimates on the glacier complex Kongsvegen and Sveabreen, Spitsbergen, Svalbard, using radioactive layers. J. Glaciol. 40(135), 368-376.

Liestøl, O. 1977: Pingos, springs and permafrost in Spitsbergen. Norsk Polarinst. Arbok 1975, 7-29.

Liston, G. E. \& Sturm, M. in press: A snow-transport model for complex terrain. J. Glaciol.

Pomeroy, J. W., Gray, D. M. \& Landine, P. G. 1993: The Prairie Blowing Snow Model: characteristics, validation, operation. J. Hydrol. 144, 165-192.

Sand, K. \& Winther, J-G. 1992: Polar hydrology: Norwegian activity in Svalbard (In Norwegian). Pp. 693-702 in Østrem, G. (ed.): Proceedings of the 17th Nordic Hydrological Conference, Alta, Norway.

Takeuchi, Y., Kodoma, Y. \& Nakabayashi, H. 1995: Characteristics of evaporation from snow and tundra surface in Spitsbergen in the snowmelt season 1993. Proc. NIPR Symp. Polar Meteorol. Glaciol. 9, 54 65.

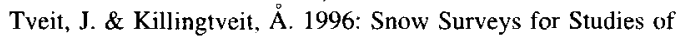
Water Budget on Svalbard 1991-1994. Pp. 489-509 in Sand, K. \& Killingtveit, $\AA$. (eds.): Proceedings of the $10 \mathrm{th}$ Northern Research Basins Symposium and Workshop, Spitsbergen. Norway. 